\title{
GAMBARAN KADAR TRIASILGLISEROL DARAH MAHASISWA ANGKATAN 2011 FAKULTAS KEDOKTERAN UNIVERSITAS SAM RATULANGI DENGAN INDEKS MASSA TUBUH 18,5-22,9 kg/m²
}

\author{
${ }^{1}$ Miranti Kumesan \\ ${ }^{2}$ Diana Purwanto \\ ${ }^{2}$ Yanti Mewo
${ }^{1}$ Kandidat Skripsi Fakultas Kedokteran Universitas Sam Ratulangi Manado
${ }^{2}$ Bagian Biokimia Fakultas Kedokteran Universitas Sam Ratulangi Manado
Email:mirantikumesan@ymail.com

\begin{abstract}
In Indonesia, the incidence of degenerative disease has been raising. The main contributors to the degenerative disease are unhealthy modern lifestyle, smoking habit, drinking alcohol, irregularly diet and less physical activity. Blood triacylglycerol level is also a risk factor for degenerative disease. Body mass index (BMI) has a correlation with blood triacylglycerol level. A normal body mass index also has a normal mean of blood triacylglycerol level. The purpose of this study is to find out the blood triacylglycerol level in students year 2011 Medical Faculty of Sam Ratulangi University with body mass index 18,5-22,9 kg/m². This study was a descriptive study with cross sectional design. The sample was taken with purposive method sampling. There were 31 participants on this study. The result of this study was 31 participants had normal blood triacylglycerol level. Conclusion: The blood triacylglycerol level in students year 2011 Medical Faculty of Sam Ratulangi University with body mass index 18,5$22,9 \mathrm{~kg} / \mathrm{m}^{2}$ is normal.
\end{abstract}

Keywords: BMI, triacylglycerol.

\begin{abstract}
Abstrak: Di Indonesia telah terjadi peningkatan kejadian penyakit degeneratif. Kontributor utama terjadinya penyakit degeneratif ialah gaya hidup modern yang tidak sehat seperti kebiasaan merokok, minum alkohol, pola makan yang tidak teratur dan aktivitas fisik yang kurang. Kadar triasilgliserol dalam darah juga merupakan faktor risiko terjadinya berbagai penyakit degeneratif. Indeks massa tubuh (IMT) memiliki korelasi bermakna dengan kadar triasilgliserol darah. Pada indeks massa tubuh normal, rata-rata kadar triasilgliserol darah juga normal. Tujuan penelitian ini ialah untuk mengetahui gambaran kadar triasilgliserol darah mahasiswa angkatan 2011 Fakultas Kedokteran Unsrat dengan indeks massa tubuh 18,5-22,9 $\mathrm{kg} / \mathrm{m}^{2}$. Penelitian ini merupakan penelitian deskriptif dengan desain cross sectional. Pengambilan sampel dengan metode purposive sampling. Jumlah responden dalam penelitian ini 31 orang. Pada penelitian ini diperoleh hasil 31 responden memiliki kadar triasilgliserol normal. Simpulan: Gambaran kadar triasilgliserol darah mahasiswa angkatan 2011 Fakultas Kedokteran Unsrat dengan indeks massa tubuh 18,5-22,9 kg/m² ialah normal.
\end{abstract}

Kata kunci: IMT, triasilgliserol.

Di Indonesia telah terjadi peningkatan kejadian penyakit degeneratif. Penyakit degeneratif merupakan penyakit tidak menular yang berlangsung kronis seperti penyakit kardiovaskuler dan obesitas. Penyakit kardiovaskuler yang utama ialah penyakit jantung koroner dan hipertensi. Sampai saat ini penyakit degeneratif telah menjadi penyebab kematian terbesar di dunia. Hampir 17 juta orang meninggal setiap tahun akibat penyakit degeneratif. ${ }^{1}$ Tahun 2008, prevalensi penyakit 
kardiovaskuler di dunia sebesar 82,6 juta $(36,2 \%)$ dan stroke 7 juta $(3 \%)^{2}{ }^{2} \mathrm{Di}$ Indonesia, prevalensi penyakit jantung sebesar 7,2\% dan stroke 8,3\%o. Di Sulawesi Utara prevalensi penyakit jantung 8,2\% dan stroke $10,4 \%$. $^{3}$

Kontributor utama terjadinya penyakit degeneratif ialah gaya hidup modern yang tidak sehat seperti kebiasaan merokok, minum alkohol, pola makan yang tidak teratur, dan aktivitas fisik yang kurang. ${ }^{1}$ Kadar triasilgliserol dalam darah juga merupakan faktor risiko terjadinya berbagai penyakit degeneratif. ${ }^{4,5}$ Peningkatan kadar triasilgliserol meningkatkan risiko terjadinya penyakit kardiovaskuler karena hubungannya dengan partikel sisa yang bersifat aterogenik dan apo $\mathrm{C}_{\mathrm{III}}{ }^{4}$ Peningkatan kadar triasilgliserol juga berhubungan dengan peningkatan risiko stroke iskemik. Hal ini dikarenakan peningkatan kadar triasilgliserol merupakan penanda peningkatan lipoprotein sisa yaitu kilomikron sisa dan very low density lipoprotein (VLDL). Partikel lipoprotein sisa ini dapat berpenetrasi ke dinding arteri, melepaskan kolesterol ke intima dan memicu terjadinya aterosklerosis.,

Pada penelitian yang dilakukan oleh Supriyono $^{7}$ pada pasien penyakit jantung koroner (PJK) berusia $\leq 45$ tahun dan sebagai kontrol pasien yang tidak menderita PJK, menunjukkan adanya hubungan yang bermakna antara kenaikan kadar triasilgliserol dalam darah dengan kejadian PJK. Kadar triasilgliserol dalam darah yang tinggi ( $\geq 150 \mathrm{mg} / \mathrm{dL}$ ) meningkatkan risiko terjadinya PJK sebesar 2,8 kali lebih besar dibandingkan dengan kadar triasilgliserol normal ( $<150 \mathrm{mg} / \mathrm{dL})$.

Sitorus $^{8}$ juga melakukan penelitian untuk mengetahui faktor risiko stroke pada usia muda $<40$ tahun, dengan kelompok kasus pasien yang menderita stroke $<40$ tahun dan sebagai kontrol pasien stroke $>50$ tahun. Pada penelitian ini didapat hasil bahwa risiko terjadinya stroke pada responden dengan kadar triasilgliserol darah $\geq 150 \mathrm{mg} / \mathrm{dL} \quad 1,46$ kali lebih besar dibandingkan responden dengan kadar triasilgliserol darah $<150 \mathrm{mg} / \mathrm{dL}$.
Prevalensi kadar triasilgliserol tinggi ( $\geq 150 \mathrm{mg} / \mathrm{dL}$ ) pada orang dewasa usia 20-29 tahun di Amerika Serikat berdasarkan data dari National Health and Nutrition Examination Survey (NHANES) tahun 1999-2008 yaitu sebesar 20,7\%. ${ }^{4}$ Berdasarkan data NHANES tahun 19992006, remaja usia 18-19 tahun di Amerika Serikat memiliki prevalensi kadar triasilgliserol tinggi sebesar $16,4 \% .{ }^{9}$

Indeks massa tubuh (IMT) merupakan alat yang dapat mengukur status gizi dan kandungan lemak dalam tubuh seseorang. $^{10,11}$ Pada penelitian Sinsanta $\mathrm{dkk}^{12}$, didapat hasil adanya korelasi bermakna antara IMT dan kadar triasilgliserol, dengan derajat hubungan yang rendah. Hal ini berarti bila nilai IMT tinggi, tidak selalu diikuti peningkatan nilai kadar triasilgliserol, tetapi ada kemungkinan peningkatan IMT yang diikuti oleh peningkatan kadar triasilgliserol. Pada penelitian Raju $\mathrm{dkk}^{13}$ serta Choi $\mathrm{dkk}^{14}$, didapat hasil seseorang dengan indeks massa tubuh normal memiliki rata-rata kadar triasilgliserol yang normal. Berbeda dengan hasil penelitian yang didapat oleh Idapola $^{15}$ bahwa pada IMT normal terdapat kadar triasilgliserol tinggi. Demikian juga berdasarkan data dari NHANES tahun 19992006 pada remaja usia 12-19 tahun dengan IMT normal di Amerika Serikat memiliki prevalensi kadar triasilgliserol tinggi $(\geq 150$ $\mathrm{mg} / \mathrm{dL}$ ) sebesar 5,9\%. ${ }^{9}$

Kadar triasilgliserol yang tinggi dapat meningkatkan berbagai risiko penyakit dan hal tersebut dapat terjadi walaupun seseorang masih berusia muda dan memiliki indeks massa tubuh normal. Tujuan penelitian ini ialah untuk mengetahui gambaran kadar triasilgliserol darah mahasiswa angkatan 2011 Fakultas Kedokteran Universitas Sam Ratulangi dengan indeks massa tubuh 18,5-22,9 kg/ $\mathrm{m}^{2}$.

\section{METODE PENELITIAN}

Penelitian ini merupakan penelitian deskriptif dengan desain penelitian cross sectional. Sampel penelitian berjumlah 31 orang responden yang didapat dengan 
metode pengambilan sampel purposive sampling, yaitu memilih sampel yang sesuai dengan kriteria tertentu: mahasiswa angkatan 2011 Fakultas Kedokteran Unsrat Program Studi Pendidikan Dokter, IMT 18,5-22,9 kg/m², usia minimal 18 tahun, dan bersedia menjadi responden.

Pengambilan sampel dilakukan dengan menggunakan kuesioner untuk mendapatkan responden yang sesuai dengan kriteria. Responden yang terpilih menjadi sampel penelitian diukur berat badan dan tinggi badan, serta diminta mengisi dan menandatangani informed consent.

Indeks massa tubuh diukur dengan rumus berat badan dalam kilogram (kg) dibagi kuadrat tinggi badan dalam meter $\left(\mathrm{m}^{2}\right)$. Indeks massa tubuh normal ialah indeks massa tubuh dalam rentang 18,5-22,9 $\mathrm{kg} / \mathrm{m}^{2}$ menurut kriteria Asia-Pasifik. ${ }^{16}$ Pemeriksaan kadar triasilgliserol dilakukan dengan mengambil darah pada pembuluh darah vena cubiti setelah puasa 10-12 jam. Kadar triasilgliserol darah dinilai berdasarkan klasifikasi menurut National Cholesterol Education Program Adult Treatment Panel III (NCEP ATP III). ${ }^{17}$

\section{HASIL PENELITIAN}

Jumlah responden pada penelitian ini ialah 31 responden, laki-laki 9 orang dan perempuan 22 orang, dengan indeks massa tubuh normal $\left(18,5-22,9 \mathrm{~kg} / \mathrm{m}^{2}\right)$ (Tabel 1). Rentang usia responden ialah 18-20 tahun.

Hasil pemeriksaan kadar triasilgliserol darah didapat 31 responden memiliki kadar triasilgliserol normal $(<150 \mathrm{mg} / \mathrm{dL}$ ). Ratarata kadar triasilgliserol darah responden ialah 64,65 \pm 25,86 mg/dL (Tabel 2).

Tabel 1. Karakteristik responden berdasarkan jenis kelamin

\begin{tabular}{ccc}
\hline Usia & Jumlah (n) & Persentase (\%) \\
\hline Laki-laki & 9 & 29 \\
Perempuan & 22 & 71 \\
\hline Jumlah & 31 & $100 \%$ \\
\hline
\end{tabular}

Tabel 2. Nilai rata-rata kadar triasilgliserol menurut jenis kelamin

\begin{tabular}{lcc}
\hline Kelompok & Mean & SD \\
\hline Laki-laki & 70,00 & 18,29 \\
Perempuan & 62,45 & 28,47 \\
Laki-laki dan & 64,65 & 25,86 \\
perempuan & & \\
\hline
\end{tabular}

\section{BAHASAN}

Pada penelitian ini didapat hasil responden dengan IMT normal memiliki kadar triasilgliserol normal. Hasil penelitian ini sesuai dengan beberapa hasil penelitian sebelumnya. Raju dkk ${ }^{13}$ melakukan penelitian pada 176 responden usia 18-23 tahun yang memiliki IMT normal, dengan hasil penelitian yang didapat pada IMT normal memiliki rata-rata kadar triasilgliserol normal yaitu 88,47 \pm 9,57 mg/dL pada laki-laki dan 92,15 \pm 9,57 $\mathrm{mg} / \mathrm{dL}$ pada perempuan. Choi $\mathrm{dkk}^{\overline{14}}$ juga melakukan penelitian pada 536 responden usia 14-19 tahun dengan IMT normal dan didapat hasil pada IMT normal memiliki rata-rata kadar triasilgliserol normal yaitu 93,9 \pm 41,3 mg/dL pada laki-laki dan 89,7 + 41,4 mg/dL pada perempuan. Pada penelitian yang dilakukan Sanlier dan Yabanci $^{18}$ pada 230 orang usia 19-23 tahun dengan IMT normal juga didapatkan hasil pada IMT normal memiliki rata-rata kadar triasilgliserol normal yaitu 93,0 \pm 42,0 $\mathrm{mg} / \mathrm{dL}$. Aziz $\mathrm{dkk}^{19}$ juga melakukan penelitian pada 175 responden usia 17-22 tahun dengan IMT normal dan didapat hasil yang sama dengan penelitian lain bahwa pada IMT normal memiliki rata-rata kadar triasilgliserol normal yaitu 89,2 \pm 41,6 $\mathrm{mg} / \mathrm{dL}$. Hasil penelitian ini sama dengan hasil penelitian sebelumnya karena karakteristik responden yang sama yaitu pada usia muda dengan IMT yang normal.

Pada keadaan puasa, triasilgliserol di darah terutama berasal dari sintesis triasilgliserol di hati. ${ }^{20}$ Asam lemak bebas dari sirkulasi merupakan sumber utama pembentukan triasilgliserol selama keadaan puasa. Asam lemak bebas dari sirkulasi berasal dari lipolisis triasilgliserol di jaringan adiposa. $^{21}$ 
Asam lemak yang dilepaskan dari hasil lipolisis triasilgliserol di jaringan adiposa, beberapa masuk ke aliran darah dan sisanya digunakan kembali di jaringan adiposa untuk resintesis triasilgliserol. Beberapa asam lemak yang dilepaskan di darah akan digunakan sebagai energi (misalnya, pada otot) dan beberapa asam lemak lainnya akan diangkut ke hati untuk sintesis triasilgliserol. $^{22}$ Selain diubah menjadi triasilgliserol, asam lemak di hati dapat pula diubah menjadi badan keton. Asam lemak akan mengalami oksidasi parsial menyebabkan terbentuknya badan keton. Badan keton juga digunakan sebagai bahan bakar dalam keadaan puasa lama dan kelaparan. ${ }^{23}$

Hampir 30\% asam lemak yang memasuki hati pada suatu keadaan puasa mengalami esterifikasi menjadi triasilgliserol dan ditransportasikan dalam darah dalam bentuk VLDL. ${ }^{24}$ Kadar normal triasilgliserol di darah pada keadaan puasa dipengaruhi kontrol hormon yang normal pada lipolisis jaringan adiposa, penggunaan asam lemak sebagai energi di jaringan dan sintesis triasilgliserol di hati. ${ }^{21,22}$

Hasil penelitian ini berbeda dengan hasil penelitian yang didapat oleh Idapola dan Singal. Idapola ${ }^{15}$ melakukan penelitian pada 61 responden usia 20-55 tahun dengan IMT normal. Pada penelitian Idapola didapatkan hasil bahwa pada IMT normal terdapat 15 orang $(22,4 \%)$ yang memiliki kadar triasilgliserol tinggi $(\geq 150 \mathrm{mg} / \mathrm{dL})$. Singal $^{25}$ juga melakukan penelitian pada 22 responden laki-laki usia 40-50 tahun dengan IMT normal. Pada penelitian Singal didapatkan hasil bahwa pada IMT normal terdapat 2 orang (9,09\%) yang memiliki kadar triasilgliserol dalam batas tinggi (150-199 $\mathrm{mg} / \mathrm{dL})$ dan 3 orang $(13,63 \%)$ yang memiliki kadar triasilgliserol tinggi (200$500 \mathrm{mg} / \mathrm{dL}$ ). Pada kedua penelitian ini dinyatakan pada IMT normal terdapat kadar triasilgliserol tinggi $(\geq 150 \mathrm{mg} / \mathrm{dL}) .{ }^{15,25}$ Hasil penelitian ini berbeda dengan hasil penelitian Idapola dan Singal karena responden pada penelitian Idapola dan Singal memiliki usia yang lebih tua.

Kadar triasilgliserol tinggi pada IMT normal dipengaruhi oleh usia. Berdasarkan penelitian Idapola dan Singal, kadar triasilgliserol tinggi lebih banyak terdapat pada usia dewasa tua (40-50 tahun). ${ }^{15,25}$ Hal ini berkaitan dengan kebiasaan merokok dan konsumsi alkohol berlebihan. ${ }^{25}$

Kebiasaan merokok yang sudah berlangsung lama (satu sampai lima tahun atau lebih) dan jumlah konsumsi rokok yang banyak (satu sampai sepuluh batang atau lebih per hari), dapat meningkatkan kadar triasilgliserol. ${ }^{26,27}$ Pada penelitian yang dilakukan oleh $\mathrm{Neki}^{26}$ dan Devaranavadgi $\mathrm{dkk}^{27}$, didapat hasil rata-rata kadar triasilgliserol yang lebih tinggi pada perokok daripada yang bukan perokok.

Rokok dapat meningkatkan kadar triasilgliserol berhubungan dengan zat nikotin yang terdapat pada rokok. Nikotin akan merangsang sekresi ketekolamin, kortisol dan hormon pertumbuhan, yang kemudian akan mengaktifkan adenilil siklase. Enzim adenilil siklase akan memicu lipolisis triasilgliserol di jaringan adiposa sehingga terjadi peningkatan asam lemak bebas di plasma. Asam lemak bebas kemudian diangkut ke hati sehingga terjadi peningkatan produksi triasilgliserol di hati. ${ }^{27}$

Konsumsi alkohol yang berlebihan dapat menyebabkan hipertriasilgliserolemia. ${ }^{28}$ Pada penelitian yang dilakukan oleh Seo $\mathrm{dkk}^{29}$, didapatkan hasil rata-rata kadar triasilgliserol yang lebih tinggi pada peminum alkohol kronik daripada yang tidak meminum alkohol. Pada konsumsi alkohol berlebihan terjadi peningkatkan oksidasi alkohol oleh alkohol dehidrogenase sehingga terjadi pula peningkatan produksi nikotinamid adenin dinukleotida hidrogen (NADH). Nikotinamid adenin dinukleotida hidrogen yang berlebihan di hati akan menghambat oksidasi asam lemak sehingga terjadi peningkatan esterifikasi asam lemak menjadi triasilgliserol. ${ }^{21}$

Pada usia muda dengan IMT normal, kadar triasilgliserol cenderung normal. Hal ini dikarenakan metabolisme triasilgliserol yang berlangsung normal dan tidak terdapatnya faktor-faktor yang dapat meningkatkan kadar triasilgliserol seperti kebiasaan merokok dan minum alkohol berlebihan. Semua responden pada penelitian ini tidak 
didapati ada kebiasaan merokok dan minum alkohol.

Kekurangan dalam penelitian ini ialah jumlah sampel penelitian yang sedikit. Selain itu tidak diteliti variabel lain yang dapat mempengaruhi kadar triasilgliserol darah, seperti aktivitas fisik dan pola makan.

\section{SIMPULAN}

Berdasarkan hasil penelitian terhadap 31 responden mahasiswa angkatan 2011 Fakultas Kedokteran Unsrat Program Studi Pendidikan Dokter dengan indeks massa tubuh 18,5-22,9 $\mathrm{kg} / \mathrm{m}^{2}$, dapat disimpulkan bahwa semua responden (100\%) memiliki kadar triasilgliserol normal.

\section{UCAPAN TERIMA KASIH}

Ucapan terima kasih disampaikan pada dr. Youla Assa, MKes, dr. Murniati Tiho, MKes, dan pada semua pihak yang telah menumbuhkan ide atau gagasan dalam pemikiran penulis sehingga dapat menyelesaikan artikel ini.

\section{DAFTAR PUSTAKA}

1. Handajani A, Roosihermiatie B, Maryani H. Faktor-faktor yang berhubungan dengan pola kematian pada penyakit degeneratif di Indonesia. Buletin penelitian sistem kesehatan. 2009;13(1):42-53.

2. Roger VL, Go AS, Lloyd-Jones DM, Adams RJ, Berry JD, Brown TM, et al. Heart disease and stroke Statistics 2011 update: a report from the american heart association. Circulation. 2011;123:18-209.

3. Badan Penelitian dan Pengembangan Kesehatan Departemen Kesehatan Republik Indonesia. Riset kesehatan dasar 2007. Jakarta; 2008.hal.111-5.

4. Miller M, Stone NJ, Ballantyne C, Bittner $\mathrm{V}$, Criqui MH, Ginsberg $\mathrm{HN}$, et al. Triglycerides and cardiovascular disease: a scientific statement from the american heart association. Circulation. 2011;123:2292333.

5. Botham KM, Mayes PA. Sintesis, transpor dan eksresi kolesterol. Dalam: Wulandari N, Rendy L, Dwijayanthi L, Liena, Dany F, Rachman LY, editor. Biokimia harper. Edisi
27. Alih bahasa: Pendit BU. Jakarta: EGC, 2009; hal.239-49.

6. Varbo A, Nordestgaard BG, TybjærgHansen A, Schnohr P, Jensen GB, Benn M. Nonfasting triglycerides, cholesterol, and ischemic stroke in the general population. ANN NEUROL. 2011;69:628-34.

7. Supriyono M. Faktor-faktor risiko yang berpengaruh terhadap kejadian penyakit jantung koroner pada kelompok usia $\leq 45$ tahun [Tesis]. Semarang: Universitas Diponegoro; 2008.

8. Sitorus RJ, Hadisaputro S, Kustiowati E. Faktor-faktor risiko yang mempengaruhi kejadian stroke pada usia muda kurang dari 40 tahun. Epidemiologi 2008. Available from: http://eprints.undip.ac.id/6482/. Accessed on: 5 November 2012.

9. Shaw FE, editor. Prevalence of abnormal lipid levels among youth-United State 19962006. MMWR. 2010;59:29-33.

10. Department of Health and Human Services Centres for Disease Control and Prevention. Body mass index: consideration for practitioner. Available from: http://www.cdc.gov/obesity/downloads/BMI forPactitioners.pdf. Accessed on: 4 November 2012.

11. Supariasa IDN, Bakri B, Fajar I. Penilaian status gizi. Jakarta: Penerbit buku kedokteran EGC, 2001; hal.27-86.

12. Sinsanta, Sanarko LH, Iskandar I. Korelasi indeks massa tubuh dengan kadar trigliserida darah mahasiswa fakultas kedokteran ukrida tahun akademik 2004/2005. Meditek 2006;14(38):1-8.

13. Raju GM, Vijayanath V, Anitha MR. Relation of body mass index with fasting blood sugar and triglycerides level in healthy young adult medical students. Int $\mathrm{J}$ Med Toxicol Forensic Med. 2012;2:33-40.

14. Choi JW, Pai SH, Kim SK. Associations between total body fat and serum lipid concentrations in obese human adolescent. Ann Clin Lab Sci. 2002;32(3):271-8.

15. Idapola SSJ. Hubungan indeks massa tubuh dengan keadaan biokimia darah pada karyawan PT Asuransi Jiwa Bumi Asih Jaya Jakarta [Skripsi]. Jakarta: Universitas Indonesia; 2009.

16. Inoue $\mathbf{S}$, Zimmet $\mathbf{P}$. The Asia-Pasific perspective, redefining obesity and its treatment. Australia: Health communication Australia pty limited on behalf of the steering commitee, 2000. 
17. The third report of the national cholesterol education program (NCEP) expert panel on detection, evaluation, and treatment of high blood cholesterol in adult (adult treatment panel III) final report. Circulation 2002;106:3331-3.

18. Sanlier N, Yabanci N. Relationship between body mass index, lipids and homocysteine levels in university students. J Pak Med Assoc. 2007:57(10):491-5.

19. Aziz J, Siddiqui NA, Siddiqui IA, Omair A. Relation of body mass index with lipid profile and blood pressure in young healthy students at Ziauddin Medical University. J Ayub Med Coll Abbottabad. 2003;15(4):57-9.

20. Europen food safe authority. Docosahexaenoic acid (DHA) related human claims. EFSA journal. 2010:8(10);1-27.

21. Mayes P. Pengangkutan dan penyimpanan lipid. Dalam: Wulandari N, Rendy L, Dwijayanthi L, Liena, Dany F, Rachman LY, editor. Biokimia harper. Edisi 27. Alih bahasa: Pendit BU. Jakarta: EGC, 2009; hal.225-38.

22. Nelson DL, Cox MM. Lehninger principles of biochemistry ( $5^{\text {th }}$ Ed). New York: W.H. Freman, 2008; p.805-50.

23. Bender DA, Mayes PA. Tinjauan umum metabolisme dan penyediaan bahan bakar metabolik. In: Wulandari N, Rendy L,
Dwijayanthi L, Liena, Dany F, Rachman LY, editor. Biokimia Harper (Edisi ke-27). Alih bahasa: Pendit BU. Jakarta: EGC, 2009; p.139-51.

24. Voet D, Voet JG, Pratt CW. Fundamental of biochemistry life at molecular level $\left(4^{\text {th }}\right.$ Ed). Hoboken: John Wiley \& Sons, 2008; p.657-711.

25. Singal MS. Gambaran kadar triasilgliserol darah pada laki-laki usia 40-50 tahun dengan indeks massa tubuh 18,5-22,9 kg/m [Skripsi]. Manado: Universitas Sam Ratulangi; 2012.

26. Neki NS. Lipid profile in chronic smokers-a clinical study. JIACM. 2002;3(1):51-4.

27. Devaranavadgi BB, Aski BS, Kashinath RT, Hundekari IA. Effect of cigarette smoking on blood lipids-a study ini Belgaum, Northern Karnataka, India. Global journal of medical research. 2012;12:56-61

28. Van de Wiel A. The effect of alcohol on prostprandial and fasting triglycerides. International Journal of Vascular Medicine. 2012:2012:1-4.

29. Seo JS, Yang KM, Kim JM, Min H, Kim CS, Burri BJ. Effect of chronic consumption on plasma lipid, vitamin A, and $\mathrm{E}$ in Korean alcoholics. Nutrition research. 2004:24;959-68. 